\section{Crystal Structure of the Arsenate(V) $\mathrm{NaTi}_{2}\left[\mathrm{AsO}_{4}\right]_{3}$}

Hamdi Ben Yahia, Ute Ch. Rodewald, and Rainer Pöttgen

Institut für Anorganische und Analytische Chemie, Universität Münster, Corrensstraße 30, 48149 Münster, Germany

Reprint requests to R. Pöttgen.

E-mail: pottgen@uni-muenster.de

Z. Naturforsch. 2010, 65b, 639-642; received February 22, 2010

The arsenate $(\mathrm{V}) \mathrm{NaTi}_{2}\left[\mathrm{AsO}_{4}\right]_{3}$ has been synthesized by a solid-state reaction route using a salt flux. Its structure has been solved and refined from single-crystal X-ray data: NASICON-type, $R \overline{3} c, a=8.8057(5), c=22.2406(15) \AA$. $Z=6$, $w R\left(F^{2}\right)=0.0617$ for 576 unique reflections and 30 variables. The $\mathrm{NaTi}_{2}\left[\mathrm{AsO}_{4}\right]_{3}$ structure consists of a three-dimensional framework of corner-sharing $\mathrm{AsO}_{4}$ tetrahedra and $\mathrm{TiO}_{6}$ octahedra. The negatively charged $\left[\mathrm{Ti}_{2} \mathrm{As}_{3} \mathrm{O}_{12}\right]$ framework gives rise to two different interstices. The $\mathrm{Na}^{+}$cation is located on the $6 b$ position with a trigonal antiprismatic coordination and enhanced anisotropic displacement parameters.

Key words: Crystal Structure, Nasicon, Arsenate(V), Single Crystal Diffraction, Salt Flux Synthesis

\section{Introduction}

In the last three decades, complex oxides with the general formula $A A_{3}^{\prime} B_{2}\left[X \mathrm{O}_{4}\right]_{3}$, where $A$ are monovalent (alkali, $\mathrm{Cu}^{+}, \mathrm{Ag}^{+}, \ldots$ ), divalent (alkaline earth, $\left.\mathrm{Mn}^{2+}, \mathrm{Cu}^{2+}, \mathrm{Zn}^{2+}, \ldots\right)$ or trivalent (rare earth) cations, $B$ trivalent $\left(\mathrm{Fe}^{3+}, \mathrm{Er}^{3+}, \ldots\right)$, tetravalent $\left(\mathrm{Ti}^{4+}\right.$, $\left.\mathrm{Sn}^{4+}, \mathrm{Ge}^{4+}, \ldots\right)$ or even pentavalent $\left(\mathrm{Nb}^{5+}, \mathrm{Sb}^{5+}, \ldots\right)$ cations, and $X=\mathrm{As}, \mathrm{Ge}, \mathrm{Mo}, \mathrm{P}, \mathrm{Si}$ have been widely studied. Besides the rich structural chemistry, the interest in these materials mainly concerns the remarkable electrochemical properties of selected oxides with potential application as solid electrolytes, gas sensors, or battery materials $[1-8]$.

The NASICON structure of $\mathrm{Na}_{4} \mathrm{Zr}_{2}\left[\mathrm{SiO}_{4}\right]_{3}$ was first reported by Sizova et al. [9]. It is characterized by a three-dimensional framework of $\mathrm{BO}_{6}$ octahedra, sharing corners with $\mathrm{XO}_{4}$ tetrahedra and forming tunnels which may be vacant $\left(\square_{4} \mathrm{NbTi}\left[\mathrm{PO}_{4}\right]_{3}\right)$ [10], partially filled $\left(\square_{1} \mathrm{Na}_{3} \mathrm{Fe}_{2}\left[\mathrm{PO}_{4}\right]_{3}\right.$ [11], $\mathrm{Ag} \square_{3} \mathrm{Ge}_{2}\left[\mathrm{PO}_{4}\right]_{3}$ [12],
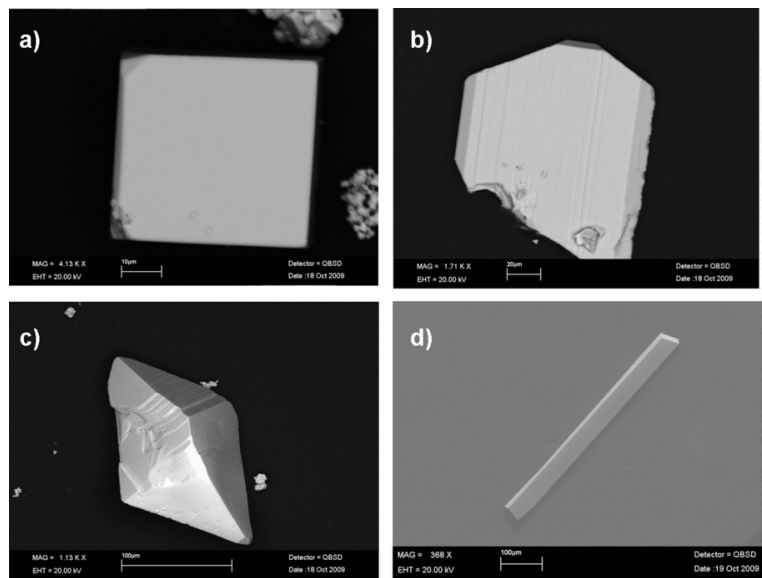

Fig. 1. Scanning electron micrograph of (a) the $\mathrm{NaTi}_{2}\left[\mathrm{AsO}_{4}\right]_{3}$ single crystal used for the XR data collection, (b) $\mathrm{KTiO}\left[\mathrm{AsO}_{4}\right]$ and (c, d) $\mathrm{NaTiO}\left[\mathrm{AsO}_{4}\right]$ single crystals.

$\mathrm{Sr}_{0.5} \square_{0.5} \square_{3} \mathrm{Zr}_{2}\left[\mathrm{AsO}_{4}\right]_{3}$ [13], $\mathrm{Ca} \square_{3} \mathrm{TiFe}\left[\mathrm{PO}_{4}\right]_{3}$ [14], $\operatorname{Pr}_{0.33} \square_{0.67} \square_{3} Z_{2}\left[\mathrm{PO}_{4}\right]_{3}$ [15]), or fully occupied by $A$ and $A^{\prime}$ ions $\left(\mathrm{Na}_{4} \mathrm{Zr}_{2}\left[\mathrm{SiO}_{4}\right]_{3}\right.$ [9]). The $A$ ions are sandwiched between two $\mathrm{BO}_{6}$ octahedra along the $c$ axis giving rise to a trigonal antiprismatic coordination whereas the $A^{\prime}$ ions are 6 - or $(6+2)$-coordinated to the oxygen atoms depending on the composition $[9,11]$. These few examples underline the rich crystal chemistry of NASICON-related materials.

During our recent salt flux synthesis of arsenide oxides $[16,17]$ we obtained $\mathrm{NaTiO}\left[\mathrm{AsO}_{4}\right][18]$ with LT$\mathrm{CaTiO}\left[\mathrm{SiO}_{4}\right]$-type structure as a by-product. During the bulk synthesis of $\mathrm{NaTiO}\left[\mathrm{AsO}_{4}\right]$ a new arsenate(V), $\mathrm{NaTi}_{2}\left[\mathrm{AsO}_{4}\right]_{3}$, was discovered. Its crystal structure is reported herein.

\section{Experimental Section}

Synthesis

$\mathrm{NaTi}_{2}\left[\mathrm{AsO}_{4}\right]_{3}$ was prepared by solid-state reaction from a mixture of arsenic (Sigma-Aldrich, 99.999\%), titanium dioxide (Chempur, $>99.99 \%$ ) and a $\mathrm{NaCl}$ (Merck, $>99.5 \%) / \mathrm{KCl}$ (Chempur, $99.9 \%$ ) salt flux (1:1 molar ratio) with a $2: 3: 10$ molar ratio. The arsenic was purified by fractional sublimation [16]. The mixture was put in an alumina tube which was sealed under vacuum in a silica tube. The tube was heated at $500{ }^{\circ} \mathrm{C}$ for $12 \mathrm{~h}$ and at $850{ }^{\circ} \mathrm{C}$ for $48 \mathrm{~h}$ under controlled partial pressure of oxygen $\left(\mathrm{KClO}_{4}\right)$. By decreasing the temperature at a rate of $20{ }^{\circ} \mathrm{C} / \mathrm{h}$ to r.t. we obtained few colorless crystals of $\mathrm{NaTi}_{2}\left[\mathrm{AsO}_{4}\right]_{3}$ (cubes), 


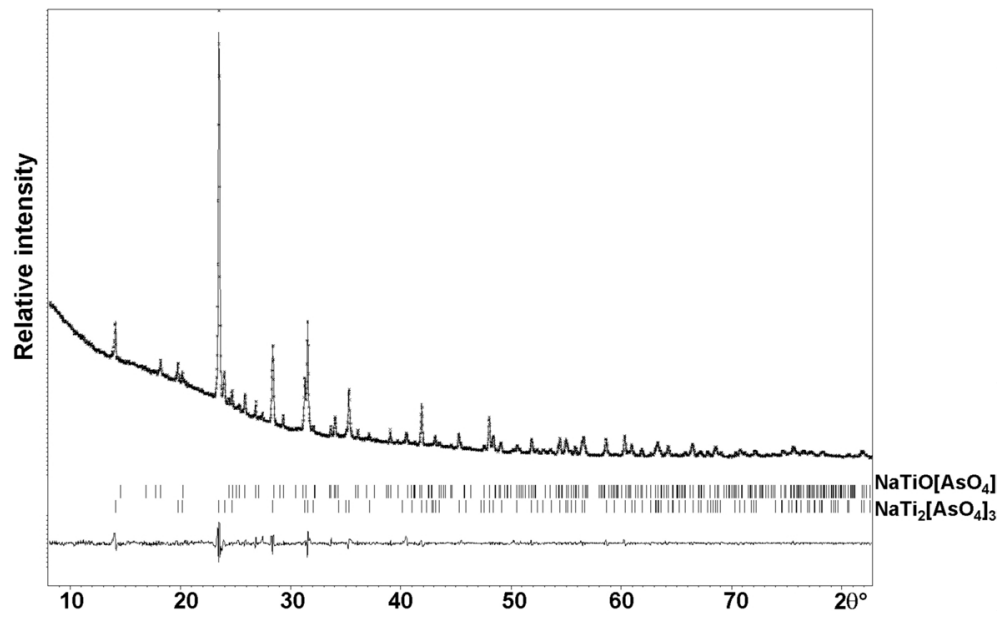

Fig. 2. Observed, calculated and difference plots for the XRPD profile refinement of the $\mathrm{NaTi}_{2}\left[\mathrm{AsO}_{4}\right]_{3}$ sample obtained from flux syntheses. The peak positions of the impurity phase $\mathrm{NaTiO}\left[\mathrm{AsO}_{4}\right]$ are also indicated.
Table 1. Crystallographic data and structure refinement for $\mathrm{NaTi}_{2}\left[\mathrm{AsO}_{4}\right]_{3}$.

\begin{tabular}{|c|c|}
\hline Formula & $\mathrm{NaTi}_{2}\left[\mathrm{AsO}_{4}\right]_{3}$ \\
\hline Crystal color / shape & colorless / cube \\
\hline$M_{\mathrm{r}}, \mathrm{g} \mathrm{mol}^{-1}$ & 535.5 \\
\hline Crystal system & trigonal \\
\hline Space group & $R \overline{3} c$ \\
\hline \multicolumn{2}{|l|}{ Lattice parameters, $\AA$} \\
\hline$a, \AA$ & $8.8057(5)$ \\
\hline$c, \AA$ & $22.2406(15)$ \\
\hline Cell volume $V, \AA^{3}$ & $1493.5(2)$ \\
\hline$Z$ & 6 \\
\hline$F(000), \mathrm{e}$ & 1500 \\
\hline Density calcd., $\mathrm{g} \mathrm{cm}^{-3}$ & 3.57 \\
\hline Temperature, $\mathrm{K}$ & 293(1) \\
\hline Diffractometer & Stoe IPDS-II \\
\hline Radiation; $\lambda, \AA$ & $\operatorname{MoK}_{\alpha} ; 0.71073$ \\
\hline Monochromator & oriented graphite \\
\hline Scan mode & multi-scan \\
\hline$h k l$ range & $\pm 13, \pm 13, \pm 32$ \\
\hline$\theta_{\min } / \theta_{\max }, \operatorname{deg}$ & $3.24 / 31.94$ \\
\hline Linear absorption coeff., $\mathrm{mm}^{-1}$ & 11.6 \\
\hline Absorption correction & Gaussian \\
\hline$T_{\min } / T_{\max }$ & $0.592 / 0.657$ \\
\hline No. of reflections & 5121 \\
\hline No. of independent refl. / $R_{\text {int }}$ & $576 / 0.0296$ \\
\hline Reflections used $[I \geq 0 \sigma(I)]$ & 576 \\
\hline Refinement technique & $F^{2}$ \\
\hline No. of refined parameters & 30 \\
\hline$R$ factors $R(F) / w R\left(F^{2}\right)$ & $0.0315 / 0.0617$ \\
\hline GOF & 1.15 \\
\hline Weighting scheme & $w=1 /\left(\sigma^{2}(I)+0.0016 I^{2}\right)$ \\
\hline Diff. Fourier residues, e $\AA^{-3}$ & $-0.57 /+0.58$ \\
\hline
\end{tabular}

$\mathrm{NaTiO}\left[\mathrm{AsO}_{4}\right]$ (needles or octahedra) and $\mathrm{KTiO}\left[\mathrm{AsO}_{4}\right]$ (plates). $\mathrm{NaTi}_{2}\left[\mathrm{AsO}_{4}\right]_{3}$ was then synthesized from a stoichiometric mixture of $\mathrm{Na}_{2} \mathrm{CO}_{3}, \mathrm{NH}_{4} \mathrm{H}_{2} \mathrm{AsO}_{4}$ and $\mathrm{TiO}_{2}$. The mixture was fired at $400{ }^{\circ} \mathrm{C}$ for $6 \mathrm{~h}$ and at $750{ }^{\circ} \mathrm{C}$ for $48 \mathrm{~h}$ with intermediate grindings. The analysis of the obtained powder
Table 2. Atom positions and equivalent isotropic displacement parameters $\left(\AA^{2}\right)$ for $\mathrm{NaTi}_{2}\left[\mathrm{AsO}_{4}\right]_{3}$.

\begin{tabular}{llllll}
\hline Atom & Site & $x$ & $y$ & $z$ & $U_{\text {eq }}$ \\
\hline $\mathrm{Na}$ & $6 b$ & 0 & 0 & 0 & $0.0283(9)$ \\
$\mathrm{Ti}$ & $12 c$ & 0 & 0 & $0.14354(3)$ & $0.00755(18)$ \\
$\mathrm{As}$ & $18 e$ & $0.28614(4)$ & 0 & $1 / 4$ & $0.00772(13)$ \\
$\mathrm{O} 1$ & $36 f$ & $0.1664(4)$ & $-0.0269(4)$ & $0.18842(10)$ & $0.0246(10)$ \\
$\mathrm{O} 2$ & $36 f$ & $0.1827(3)$ & $0.1548(3)$ & $0.08635(9)$ & $0.0177(7)$ \\
\hline
\end{tabular}

showed the presence of $\mathrm{NaTiO}\left[\mathrm{AsO}_{4}\right]$ beside the major phase $\mathrm{NaTi}_{2}\left[\mathrm{AsO}_{4}\right]_{3}$. When one fires the mixture at higher temperature $\left(950{ }^{\circ} \mathrm{C}\right)$ the amount of $\mathrm{NaTi}_{2}\left[\mathrm{AsO}_{4}\right]_{3}$ decreases in favor of $\mathrm{NaTiO}\left[\mathrm{AsO}_{4}\right]$.

\section{EDX data}

Semiquantitative EDX analyses of many crystals including the one investigated on the diffractometer (Fig. 1) were carried out with a Leica 420i scanning electron microscope with Ti, InAs, MAD-10 feldspar (for $\mathrm{K}$ ), and albite (for $\mathrm{Na}$ ) as standards. The experimentally observed compositions were close to the ideal ones $\left(\mathrm{NaTi}_{2}\left[\mathrm{AsO}_{4}\right]_{3}, \mathrm{NaTiO}\left[\mathrm{AsO}_{4}\right]\right.$ and $\left.\mathrm{KTiO}\left[\mathrm{AsO}_{4}\right]\right)$.

\section{X-Ray diffraction}

The polycrystalline sample obtained after dissolving the salt flux in demineralized water was characterized by a Guinier pattern (imaging plate detector, Fujifilm BAS-1800) with $\mathrm{Cu} K_{\alpha 1}$ radiation and $\alpha$-quartz $(a=4.9130, c=$ $5.4046 \AA$ ) as an internal standard. Taking the presence of two phases $\left(\mathrm{NaTi}_{2}\left[\mathrm{AsO}_{4}\right]_{3}\right.$ and $\left.\mathrm{NaTiO}\left[\mathrm{AsO}_{4}\right]\right)$ into account, a full pattern matching refinement was performed with the JANA2006 program package [19]. The background was estimated by a Legendre function, and the peak shapes were described by a pseudo-Voigt function. This allowed us to con- 
Table 3. Anisotropic displacement parameters $\left(\AA^{2}\right)$ for $\mathrm{NaTi}_{2}\left[\mathrm{AsO}_{4}\right]_{3}$. The anisotropic displacement factor exponent takes the form: $-2 \pi^{2}\left[\left(h a^{*}\right)^{2} U_{11}+\ldots+2 h k a^{*} b^{*} U_{12}\right]$.

\begin{tabular}{lllllll}
\hline Atom & $U_{11}$ & $U_{22}$ & $U_{33}$ & $U_{12}$ & $U_{13}$ & $U_{23}$ \\
\hline $\mathrm{Na}$ & $0.0381(13)$ & $U_{11}$ & $0.0086(11)$ & $0.0191(6)$ & 0 & 0 \\
$\mathrm{Ti}$ & $0.0074(2)$ & $U_{11}$ & $0.0079(3)$ & $0.00369(12)$ & 0 & 0 \\
$\mathrm{As}$ & $0.00652(16)$ & $0.00745(19)$ & $0.00949(18)$ & $0.00373(10)$ & $0.00099(6)$ & $0.00198(11)$ \\
$\mathrm{O} 1$ & $0.0240(12)$ & $0.0331(13)$ & $0.0226(9)$ & $0.0187(10)$ & $-0.0131(9)$ & $-0.0012(10)$ \\
$\mathrm{O} 2$ & $0.0107(9)$ & $0.0143(9)$ & $0.0158(8)$ & $-0.0032(8)$ & $0.0041(7)$ & $0.0006(7)$ \\
\hline
\end{tabular}

Table 4. Interatomic distances $(\AA)$ and bond valence sums (BVS) for $\mathrm{NaTi}_{2}\left[\mathrm{AsO}_{4}\right]_{3}$. Average distance values are given in brackets.

\begin{tabular}{lll}
\hline & Distance & $\mathrm{BV}$ \\
\hline $\mathrm{Na}-\mathrm{O} 2(2 \times)$ & $2.4376(19)$ & 0.180 \\
$\mathrm{Na}-\mathrm{O} 2(4 \times)$ & $2.438(3)$ & 0.180 \\
& $\langle 2.438\rangle$ & $\mathrm{BVS}=1.08$ \\
$\mathrm{Ti}-\mathrm{O} 1(3 \times)$ & $1.883(3)$ & 0.832 \\
$\mathrm{Ti}-\mathrm{O} 2(3 \times)$ & $1.967(3)$ & 0.663 \\
& $\langle 1.925\rangle$ & $\mathrm{BVS}=4.485$ \\
$\mathrm{As}-\mathrm{O} 2(2 \times)$ & $1.665(3)$ & 1.317 \\
$\mathrm{As}-\mathrm{O} 1(2 \times)$ & $1.672(3)$ & 1.293 \\
& $\langle 1.668\rangle$ & $\mathrm{BVS}=5.22$ \\
\hline
\end{tabular}

$\mathrm{BV}=\mathrm{e}^{\left(r_{0}-r\right) / b}$ with the following parameters: $b=0.37, r_{0}\left(\mathrm{Na}^{\mathrm{I}}-\mathrm{O}\right)=$ $1.803, r_{0}\left(\mathrm{As}^{\mathrm{V}}-\mathrm{O}\right)=1.767$ and $r_{0}\left(\mathrm{Ti}^{\mathrm{IV}}-\mathrm{O}\right)=1.815[25,26]$.

firm the biphasic mixture of the sample (Fig. 2). The refined lattice parameters $(R \overline{3} c, a=8.8191(3), c=22.2749(7) \AA$ and $P 2{ }_{1} / c, a=6.7288(5), b=8.7820(4), c=7.2583(5) \AA, \beta=$ $\left.114.961(4)^{\circ}\right)$ are in agreement with those obtained by singlecrystal diffraction for $\mathrm{NaTi}_{2}\left[\mathrm{AsO}_{4}\right]_{3}$ and $\mathrm{NaTiO}\left[\mathrm{AsO}_{4}\right]$ [18], respectively.

A suitable crystal for X-ray diffraction was selected on the basis of Laue photographs on a Buerger camera (using white Mo radiation). The data collection was carried out on a Stoe IPDS-II diffractometer using $\mathrm{Mo} K_{\alpha}$ radiation. Data processing and all refinements were performed with the JANA2006 program package [19]. A Gaussian-type absorption correction was applied, and the shape was determined with the video microscope of the Stoe CCD camera. Details about the data collection and crystallographic parameters are summarized in Table 1.

\section{Structure refinement}

The extinction conditions observed for the $\mathrm{NaTi}_{2}\left[\mathrm{AsO}_{4}\right]_{3}$ crystal agreed with space group $R \overline{3} c$. The atomic positions of isotypic $\mathrm{NaTi}_{2}\left[\mathrm{PO}_{4}\right]_{3}$ [20] were used as starting parameters. With anisotropic displacement parameters for all positions, the residuals converged to the values listed in Table 1 . The refined atomic positions and anisotropic displacement parameters (ADPs) are given in Tables 2 and 3.

Further details of the crystal structure investigation may be obtained from Fachinformationszentrum Karlsruhe, 76344 Eggenstein-Leopoldshafen, Germany (fax: +49-7247808-666; e-mail: crysdata@ fiz-karlsruhe.de, http://www.fiz-
informationsdienste.de/en/DB/icsd/depot_anforderung.html) on quoting the deposition number CSD-421531.

\section{Discussion}

As emphasized in Fig. 3, the $\mathrm{NaTi}_{2}\left[\mathrm{AsO}_{4}\right]_{3}$ structure consists of a three-dimensional network of cornersharing $\mathrm{AsO}_{4}$ tetrahedra and $\mathrm{TiO}_{6}$ octahedra. The
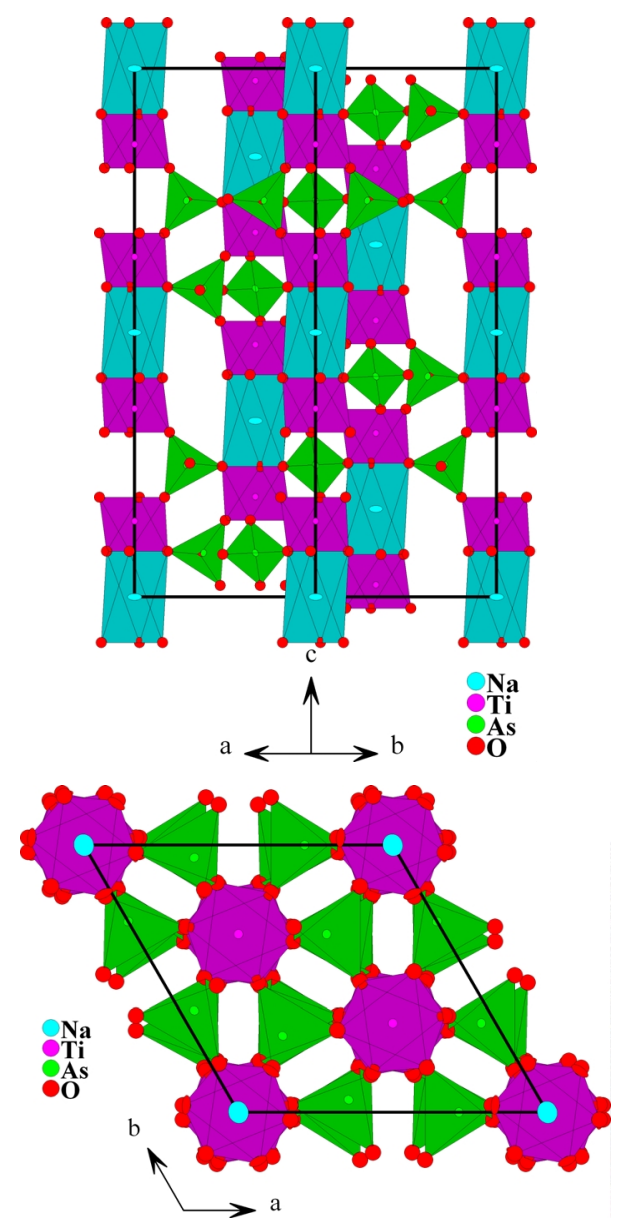

Fig. 3. (color online) View of the $\mathrm{NaTi}_{2}\left[\mathrm{AsO}_{4}\right]_{3}$ structure along [110] (top) and [001] (bottom). Relevant polyhedra are emphasized. For details see text. 
$\left[\mathrm{Ti}_{2} \mathrm{As}_{3} \mathrm{O}_{12}\right]^{1-}$ framework contains two interstices. The $\mathrm{Na}$ atom is found in a six-coordinated trigonal antiprismatic site formed by two faces of two $\mathrm{TiO}_{6}$ octahedra along the $c$ axis with $\mathrm{Na}-\mathrm{O}$ distances of $2.489 \AA$. This corresponds to the alkali ion position in $\mathrm{NaTi}_{2}\left[\mathrm{PO}_{4}\right]_{3}[20], \mathrm{KTi}_{2}\left[\mathrm{PO}_{4}\right]_{3}[21]$ and $\mathrm{RbTi}_{2}\left[\mathrm{PO}_{4}\right]_{3}$ [22]. The enhanced anisotropic displacement parameters $\left(U_{11}=U_{22}=0.0381(13) \AA^{2}\right)$ are indicative of sodium mobility as frequently observed in NASICON materials [8, and refs. therein]. The bond valence sum (BVS) of 1.08 is in good agreement with the value expected for $\mathrm{Na}^{+}$(Table 4).

A distortion is observed in the $\mathrm{TiO}_{6}$ octahedra, i.e. $3 \times 1.883$ and $3 \times 1.967 \AA$. The average Ti-O distance of $1.925 \AA$ is smaller than the value of $2.005 \AA$ estimated from the effective ionic radii of six-coordinated $\mathrm{Ti}^{4+}$ and $\mathrm{O}^{2-}$ [23]. Such short distances occur often in titanates with NASICON structure such as in
$\mathrm{LiTi}_{2}\left[\mathrm{PO}_{4}\right]_{3}\left(d_{\min }=1.880\right.$ and $\left.d_{\max }=1.976 \AA\right)$ [21], $\mathrm{CuTi}_{2}\left[\mathrm{PO}_{4}\right]_{3}\left(d_{\min }=1.896 \AA\right.$ and $\left.d_{\max }=1.958 \AA\right)[24]$ or $\mathrm{KTi}_{2}\left[\mathrm{PO}_{4}\right]_{3}\left(d_{\min }=1.886 \AA\right.$ and $\left.d_{\max }=1.933 \AA\right)$ [21]. This explains the slight overbonding of the titanium with a BVS $=4.485$. Due to this steric strain the anisotropic displacement parameters of the $\mathrm{O} 1$ oxygen atoms are enhanced (Table 3). The arsenic atoms are four-coordinated to oxygen atoms. The $\left[\mathrm{AsO}_{4}\right]$ tetrahedra are quite regular with an average As-O distance of $1.668 \AA$ which is lower than the value of $1.735 \AA$ estimated from the effective ionic radii of four-coordinated $\mathrm{As}^{5+}$ and $\mathrm{O}^{2-}$ [23]. The calculated BVS value 5.22 shows that the $\mathrm{As}^{5+}$ cation is also slightly overbonded.

\section{Acknowledgements}

This work was financially supported by the Deutsche Forschungsgemeinschaft. H. B. Y. is indebted to the Alexander von Humboldt Foundation for a research stipend.
[1] H. Y.-P. Hong, Mater. Res. Bull. 1976, 11, 173.

[2] J. B. Goodenough, H. Y.-P. Hong, J. A. Kafalas, Mater. Res. Bull. 1976, 11, 203.

[3] S. Yde-Andersen, J. S. Lundsgaard, L. Møller, J. Engell, Solid State Ionics 1984, 14, 73.

[4] E. R. Losilla, M. A. G. Aranda, S. Bruque, M. A. Paris, J. Sanz, A. R. West, Chem. Mater. 1998, 10, 665.

[5] P. Pasierb, Mater Sci.-Poland 2006, 24, 279.

[6] P. Porkodi, V. Yegnaraman, P. Kamaraj, V. Kalyanavalli, D. Jeyakumar, Chem. Mater. 2008, 20, 6410.

[7] I. V. Zatovsky, Acta Crystallogr. 2010, E66, i12.

[8] J. B. Goodenough, Y. Kim, Chem. Mater. 2010, 22, 587.

[9] R. G. Sizova, A. A. Voronkov, N. G. Shumiatskaia, V. V. Ilyukhin, N. V. Belov, Sov. Phys. Dokl. 1972, 17, 618.

[10] F. J. Berry, C. Greaves, J. F. Marco, J. Solid State Chem. 1992, 96, 408.

[11] C. Masquelier, C. Wurm, J. Rodríguez-Carvajal, J. Gaubicher, L. Nazar, Chem. Mater. 2000, 12, 525.

[12] J.-M. Winand, A. Rulmont, P. Tarte, J. Solid State Chem. 1993, 107, 356.

[13] N. G. Chernorukov, I. A. Korshunov, T. V. Prokof'eva, Kristallografiya 1978, 23, 844.

[14] A. Aatiq, H. Dhoum, Powder Diffr. 2004, 19, 157.
[15] M. Alami Talbi, R. Brochu, C. Parent, L. Rabardel, G. Le Flem, J. Solid State Chem. 1994, 110, 350.

[16] H. Lincke, R. Glaum, V. Dittrich, M. H. Möller, R. Pöttgen, Z. Anorg. Allg. Chem. 2009, 635, 936.

[17] R. Pöttgen, D. Johrendt, Z. Naturforsch. 2008, 63b, 1135 .

[18] H. Ben Yahia, U. Ch. Rodewald, R. Pöttgen, Monatsh. Chem. 2010, 141, in press.

[19] V. Petřiček, M. Dušek, L. Palatinus, JANA2006, The Crystallographic Computing System, Institute of Physics, University of Prague, Prague (Czech Republic) 2006.

[20] I. A. Ivanov, E. L. Belokoneva, Y. K. Egorov Tismenko, M. A. Simonov, N. V. Belov, Sov. Phys. Dokl. 1980, 25, 420.

[21] D. A. Woodcock, P. Lightfoot, J. Mater. Chem. 1999, 9, 2907.

[22] R. Duhlev, Acta Crystallogr. 1994, C50, 1525.

[23] R. D. Shannon, Acta Crystallogr. 1976, A32, 751.

[24] E. M. McCarron III, J. C. Calabrese, M. A. Subramanian, Mater. Res. Bull. 1987 22, 1421.

[25] I. D. Brown, D. Altermatt, Acta Crystallogr. 1985, B41, 244.

[26] N. E. Brese, M. O’Keefe, Acta Crystallogr. 1991, B47, 192. 